\author{
난황 중의 항-Salmonella gallinarum 특이 항체 생성 및 \\ 가공 특성 \\ 노정해*·김미현*.김영붕*·성기승*.이남형** \\ 한국식품연구원*, 에그바이오택**
}

\title{
Formation and Processing Properties of Anti-Salmonella gallinarum Specific IgY from Yolk
}

\author{
J. H. Rho*, M. H. Kim*, Y. B. Kim*, K. S. Sung* and N. H. Lee**
}

Korea Food Research Institute*, Egg Biotech Corporation**

\begin{abstract}
Immunization of layers against Salmonella gallinarum(S.G.) which causes fowl typhoid resulted in production of anti-S.G. IgY rich eggs. Water soluble fraction was obtained from egg yolk using various gum solutions such as $0.1 \%$ (Sigma C-3889) $\lambda$-carrageenan; $1 \%$ and $2 \%$ cold water soluble carrageenan; $1 \%$ and $2 \%$ hot water soluble carrageenan; and $1 \%$ cold water soluble carrageenan with $1 \%$ hot water soluble carrageenan. Among them, $\lambda$ -carrageenan $0.1 \%$ treatment showed a high recovery rate, possessing high IgY contents. In the range of $\mathrm{pH} 5-9$, more than 70 percent of IgY was existent. Moreover, Anti-S.G. IgY was relatively heat-stable. This study revealed that immunoglobulin against fowl typhoid could be produced successfully by layers and the IgY was sustainable to further processing due to its $\mathrm{pH}$ and heat stability. $\operatorname{IgY}$ is promising to be utilized for prevention and treatment of fowl typhoid in industrial scale.
\end{abstract}

(Key words : Eggs, IgY, Salmonella gallinarum, Stability)

$\begin{array}{cl}\text { I . 서 론 } & \begin{array}{c}\text { 수 있는 백신이나 치료제는 별로 없는 실정이 } \\ \text { 다. 이렇듯 양계산업의 발달을 저해하는 가금 }\end{array} \\ \text { 가금티프스 병의 원인균인 살모넬라 갈리나 } & \text { 티푸스는 균의 특성상 항균제, 항생제의 투여 } \\ \text { 륨(Salmonella gallinarum)은 국내에서 1992년 최 } & \text { 로 인한 완전한 예방 및 치료가 이루어지지 않 } \\ \text { 초로 발생하여 해를 거듭할수록 발생 빈도가 } & \text { 고 있다(유, 1999). 지금까지 사독, 생독 백신 } \\ \text { 늘고 있으며, 특히 5월부터 9월까지 집중 발생 } & \text { 등 여러 방법들이 개발되었으나 현재까지도 그 } \\ \text { 되고 있다(모, 1995; 나, 1999). 가금티프스의 } & \text { 대책 방안이 미약하여 가금티푸스로 인한 농가 } \\ \text { 잠복기는 감염주령, 외부 기온, 스트레스 정도 } & \text { 의 피해를 줄이는 연구가 절실한 때이다(오, } \\ \text { 에 따라 다양한 형태로 나타나나 일반적으로 } & \text { 1999). 이러한 연구의 일환으로 생산비용이 비 } \\ \text { 성계에서는 4 5 } 5 \text { 일이면 임상증상이 나타나고, } & \text { 교적 저렴한 계란을 이용하여 가금티푸스의 항 } \\ \text { 임상증상이 나타난 후 3 4일 이내에 거의 폐사 } & \text { 체를 개발하여 가금티푸스의 예방과 치료에 도 } \\ \text { 한다(박, 1995). 현재 가금티프스를 완전 예방할 } & \text { 움이 되고자 하였다. }\end{array}$

Corresponding author : J. H. Rho, Korea Food Research Institute BaekHyun-Dong 46-1 Bundang-Gu, SungNam, Korea. Tel. 82-31-780-9060, Fax 82-31-709-9876 E-mail : drno@kfri.re.kr 
난황 중의 항체는 포유류의 IgG(immunoglobulin $\mathrm{G}$ )에 해당되나 단백질 화학적 성질이 약 간 다르고 또한 난황 유래의 항체이므로 면역 학 분야 등에서는 $\operatorname{IgY}($ immunoglobulin Y)라고 부른다 (Lee 등, 1991 ; 김 등, 2000). 어미 닭이 가진 항체가 어미 닭으로부터 알에 이행되는 성질을 이용하여 면역한 산란계의 난황에서 특 이항체(specific antibody)를 얻을 수 있다(Polson 등, 1980 ; Bade 등, 1984).

난황에서 특이항체를 얻는 방법은 기존의 방 법에 비하여 여러 가지 이점을 가지고 있다. 즉 채란의 용이함, 간단한 처리로 항체의 분리 가 가능함, 생산비용의 저렴함, 시스템화된 면 역이 가능함, 항체 섭취 시 안전성이 높음, 포 유동물유래의 항원에 대하여는 포유동물의 경 우보다 산란계에서 우수한 항체를 얻을 수 있 음 등이다(Larsson 등, 1995). 특히 산란계 한 마리가 1년간 생산하는 난황에서 약 $40 \mathrm{~g} \mathrm{IgY}$ 가 얻어지며, 그 생산성은 토끼의 경우보다 120 배 높은 것으로 보고되었다(Hatta 등, 1998).

본 연구에서는 산란계에 S. gallinarum를 면 역시켜 그로부터 생산되는 특수면역 단백질의 생산을 관찰하고 난황으로 분리된 항체의 특이 성 및 안정성을 알아보고자 하였다. 그리하여 난황으로 생산된 항-S. gallinarum 특이 $\mathrm{IgY}$ 의 가공 적절성을 평가하여 현장 적용 가능성을 살펴보고자 하였다.

\section{II. 재료 및 방법}

1. 공시 재료

균주는 수의과학검역원에서 동결건조된 Salmonella gallinarum (ATCC 9148)을 구입하여 tryptic soy broth(DIFCO, USA)에서 24시간 동안 배양 하였다. 배양이 끝난 원액은 원심분리 후 균체 를 회수하여 deep freezer $\left(-70^{\circ} \mathrm{C}\right)$ 에 보관하면서
사용하였다. S. gallinarum의 균체와 Freund's adjuvant(Difco 0638-60-6)를 $1: 1(\mathrm{v} / \mathrm{v})$ 로 emulsion 을 제조하여 15 주령의 산란계의 근육에 면역하 였다. 이 때 면역한 균체는 마리당 $10^{8} \mathrm{cfu}$ 를 사 용하였고 주사량은 $1 \mathrm{~mL}$ 를 하였다. 이후 같은 방법으로 2 주 간격으로 2 차례의 추가 면역(1차 - Adjuvant complete, Freund's 사용, 2.3차Adjuvant incomplete, Freund's 사용)을 실시하였 다(노 등, 1999). 산란계는 양지 부화장으로부터 구입한 Isabrown 48수를 사용하였으며 사료는 대추용 제일 사료에 참숯 $0.5 \%$ 를 첨가하여 사 용하였다(이 등, 1999 ; 한 등, 2000).

\section{2. 난황으로부터 항체 $(\lg Y)$ 의 분리}

$\lambda$-카라기난을 이용한 분리 : 시료 채취는 일주일 동안 산란계 48수로부터 생산된 계란 중 처리구당 일자별로 1 개 이상씩 취하여 실험 하였다. 분리된 난황은 증류수와 $1: 1$ 로 섞은 후 난황 무게의 4 배의 $0.1 \% \quad \lambda$-카라기난 용액을 첨가하였다. 이후 상온에서 30 분간 방치하고 $10,000 \times g$ 에서 15 분간 원심분리 후 침전물인 lipoprotein fraction을 제거하고 수용성단백질 분 획(water soluble protein fraction; WSF)을 What$\operatorname{man} \# 2$ 여과지로 여과하였다. 한편 분리된 시 료는 동결건조(Ilshin TD5070A, Korea)를 실시 하여 분말로 제조하였다(Hatta 등, 1990).

\section{3. 카라기난의 종류와 농도에 따른 항체의 분리}

카라기난의 종류와 농도에 따른 분리: 카라 기난의 종류와 농도 따라 난황의 $\mathrm{WSF}$ 의 회수 율 및 총 $\mathrm{IgY}$ 함량과(total $\operatorname{IgY}$ )와 항-S. gallinarum 특이 항체(specific IgY)의 함량을 비 교하기 위하여 냉수가용성 카라기난(Myungshin Chemical, Korea), 열수 가용성 카라기난(Myung- 
shin Chemical, Korea) 및 $\lambda$-카라기난(Sigma, $\mathrm{USA})$ 을 이용하여 $\operatorname{IgY}$ 를 분리하였다.

\section{4. 총 $\lg Y$ 함량의 측정(total $\lg Y)$}

우선 microplate에 rabbit anti-chick IgG antibody(sigma, C2288)의 단백질 농도가 $2 \mu \mathrm{g} / \mathrm{well}$ 이 되도록 조정하여 coating하고 세척하였다. 희석된 난황의 WSF을 넣고 반응시킨 후 세척 하여 1/10k로 Hoseradish peroxidase-conjugated anti-chick IgG Ab-HRP(Promega, G135A)를 넣었 다. 여기에 $\mathrm{HRP}$ 의 기질로는 $\mathrm{TMB}$ 를 사용하였 고 $2 \mathrm{~N}$ 황산를 이용하여 반응을 정지시킨 후 $450 \mathrm{~nm}$ 에서 흡광도를 측정하였다.

5. 항-S. gallinarum 특이 항체의 함량 (specific $\lg Y$ )

이 방법도 총 $\operatorname{IgY}$ 함량의 측정과 같이 ELISA 방법에 의해 수행하였다. 원심분리된 $S$. gallinarum 균체를 O.D. 값이 $660 \mathrm{~nm}$ 에서 0.05 가 되도록 완충액으로 희석하였다. 희석된 $S$. gallinarum 균체를 microplate에 coating하고 세 척하였다. 희석된 난황의 water soluble protein 을 넣고 반응시킨 후 세척하고 적당히 희석된 rabbit anti-chick IgG Ab-HRP를 넣는다. 여기에 $\mathrm{HRP}$ 의 기질로는 $\mathrm{TMB}$ 를 사용하였고 반응 정지 액으로 $2 \mathrm{~N}$ 황산을 이용하여 $450 \mathrm{~nm}$ 에서 흡광 도를 측정하였다.

\section{6. 항체의 $\mathrm{pH} \cdot$ 열 안정성 시험}

$\mathrm{IgY}$ 의 $\mathrm{pH}$ 열 안정성을 조사하기 위하여 $\mathrm{WSF}$ 와 조난황항체 분말을 증류수에 $1 \%, 2 \%$ 로 resuspend한 시료를 준비하였다. $\mathrm{pH}$ 안정성 실 험은 phosphate buffer를 사용하여 각 $\mathrm{pH}$ 를 $2^{\sim}$ 10 의 범위로 조정한 다음 $37^{\circ} \mathrm{C}$ 에서 4 시간 방치
후 다시 $\mathrm{pH}$ 7.0으로 조정하여 잔존하는 총 $\operatorname{IgY}$ 함량과 항-S. gallinarum 특이 항체의 함량을 측정하였다.

열 안정성을 측정하기 위해서 $50,60,70,80$ ${ }^{\circ} \mathrm{C}$ 의 수욕(JEOL TECH.)에서 $5,10 \mathrm{~min}$ 가열한 후 재빨리 냉각시켜서 잔존하는 총 $\mathrm{IgY}$ 함량과 항-S. gallinarum 특이 항체의 함량을 분석하 였다.

\section{7. 전체 $\lg Y$ 중에서 항-S. gallinarum 특이 항체의 함량분석 방법}

$\lambda$-카라기난을 이용하여 분리된 항-S. gallinarum $\mathrm{IgY}$ 용액 $0.5 \mathrm{~mL}$ 과 $S$ gallinarum $\left(\mathrm{A}_{660}=\right.$ 2.3 )을 각각 $0,0.2,0.3,0.4,0.5,0.6,0.7 \mathrm{~mL}$ 을 혼합한 다음 phosphate buffer로 $1.5 \mathrm{~mL}$ 으로 조 절하였다. $37^{\circ} \mathrm{C}$ 에서 1 시간 처리한 후 $4^{\circ} \mathrm{C}$ 하루 방치하여 면역 복합체를 형성시켰다. 이 때 균 체 분산액에서 유래하는 가용성 물질의 영향을 배제하기 위하여 IgY용액 대신 phosphate buffer 를 사용하여 위와 같이 마찬가지로 처리한 것 도 함께 준비하였다. 이를 $1,100 \times g$ 으로 20 분 원심 분리하여 면역 복합체를 제거하였다. 각 상징액의 흡광도 $280 \mathrm{~nm}$ 에서의 값을 측정하고 각기 그 값에서 항원 무첨가 처리군의 흡광도 를 뺀 수치를 균체 밀도에 대하여 최저 흡광도 를 구하였다. 이때, 흡광도는 3.0 이하의 범위 에서 난황 항체용액의 농도에 정비례함을 확인 하였으므로 이를 상대적인 단백질 농도로 간주 하였다. 용액의 전체 단백질 중 특이항체의 함 량은 다음 식으로 구하였다.

\section{III. 결과 및 고찰}

\section{1. 총 $\lg Y$ 함량의 측정}

Salmonella gallinarum를 항원으로 하여 산란 
계에 Freund's adjuvant로 면역시킨 후 생산된 계란에서 $\mathrm{IgY}$ 함량을 주별로 분석한 결과는 Fig. 1 와 같다. 총 사육기간 중 생산된 계란으 로부터 얻은 난황중의 $\mathrm{IgY}$ 함량은 $1 \mathrm{~mL}$ water soluble protein fraction(WSF) 중에 $0.76 \mathrm{mg} / \mathrm{mL}$ 으 로 이는 난황 $1 \mathrm{~g}$ 에 $2.28 \mathrm{mg}$ 에 해당하는 양이 다. 일반적으로 난황의 무게를 $15 \mathrm{~g}$ 정도로 예 상하였을 때 난황의 한 개당 $34.2 \mathrm{mg}$ 의 항체 단백질을 추출할 수 있음을 보여 주었다.

Fig. 1. Changes of total $\lg Y$ content.

* Arrows indicate vaccination of Salmonella gallinarum
또한 면역처리를 하고 몇 개월이 지난 후에도 $\operatorname{IgY}$ 함량은 별다른 영향이 없는 것으로 나타났 다.

\section{2. 항-S. gallinarum 특이 항체의 역가}

항-S. gallinarum 특이 $\mathrm{IgY}$ 는 $S$. gallinarum 처리구의 경우 Fig. 3 과 같이 3 차 접종(19주) 후 2주째 가장 높은 수치를 보여주었다. 또한 대조구에 비해 약 20 배 정도 높은 수치를 나타 내었으며 10 주 이후에는 다소 감소하는 양상을 보여주었음에도 불구하고 대조구에 비해 여전 히 11 배 이상 많은 specific $\mathrm{IgY}$ 가 잔존함이 확 인되었다. 3 차 접종 후 9 주 동안은 specific $\operatorname{IgY}$ 가 높은 수치가 유지되는 것으로 나타났으며 30 주까지 계속 유지하는 것으로 보아 추가적인 접종은 필요 없을 것으로 판단되었다.

Fig. 3. Changes of anti-Salmonella gallinarum specific IgY content.

Fig. 2. Average of total $\lg Y$ content.

\footnotetext{
A : Salmonella gallinarum vaccination egg yolk

B : Control
}

S. gallinarum로 면역처리를 실시한 처리구의 경우 총 사육기간 중 평균 $\mathrm{IgY}$ 함량은 $\mathrm{WSF} 1$ $\mathrm{mL}$ 당 $0.84 \mathrm{mg}$ 으로 면역 처리를 하지 않은 산 란계에서 생산된 계란내의 $\mathrm{IgY}$ 함량과 비교하 였을 때 유의적 차이가 없는 것으로 나타났다.

\section{3. 난황항체의 분리 효율 비교}

면역시킨 산란계의 난황은 특이항체를 함유 하고 있어 난황을 직접 소재로 사용 할 수 있 으나 난황 내의 지질은 항체 항원에 대한 반응 을 방해 할 수 있어 항체를 난황으로 분리하여 사용하는 것이 바람직하다. 난황으로부터 수용 성 단백질의 회수를 비교하기 위하여 카라기난 
종류와 농도에 따라 그 효율성을 비교하고 Table 1, Fig. 5, 6에 나타내었다.

Fig. 4. Average of anti-Salmonella gallinarum specific IgY content.

A : Salmonella gallinarum vaccination egg yolk

B : Control

분리된 난황 $25 \mathrm{~g}$ 을 $\lambda$-카라기난(Sigma C3889 ) $0.1 \%$, 냉수 가용성(MSC \#10387) 1\%, $2 \%, 90{ }^{\circ} \mathrm{C}$ 연수 가용성 (MSC \#10386) $1 \%, 2 \%$ 및 냉수 가용성 $(0.1 \%): 90^{\circ} \mathrm{C}$ 가용성 $(0.1 \%)=1$ : $1,1 \%, 2 \%$ 로 사용하여 분리하였다. $\mathrm{WSF}$ 의 회 수율은 Table 1 과 같이 $\lambda$-카라기난 $0.1 \%$ 와
$0.2 \%$ 냉수 가용성 카라기난이 가장 많았으며, total $\operatorname{IgY}$ 는 $0.1 \% 90^{\circ} \mathrm{C}$ 가용성 $+0.1 \%$ 냉수 가용 성 카라기난이 가장 많은 함량을 나타내었다 (Fig. 5). Specific $\operatorname{IgY}$ 함량은 Fig. 6와 같이 나 타내었다. Specific $\mathrm{IgY}$ 또한 $0.1 \%, 90^{\circ} \mathrm{C}$ 가용성 $+0.1 \%$ 냉수 가용성 카라기난이 가장 많았으 나, $0.1 \%$ 및 $0.2 \%$ 냉수 가용성과 $90^{\circ} \mathrm{C}$ 가용성 을 비교해 보면 냉수 가용성이 $0.1 \%$ 와 $0.2 \%$ 에 서 큰 변화 없이 다소 안정되고 많은 회수율을 나타내었다. $\lambda$-카라기난 $0.1 \%$, 냉수 가용성 $1 \%$ 비교적 좋은 회수율과 total $\mathrm{IgY}$, specific $\mathrm{IgY}$ 함량을 나타내었지만 $\lambda$-카라기난 $0.1 \%$ 가 더 나은 것으로 나타내었다.

효율을 비교한 결과 냉수 가용성 카라기난이 수율이 가장 높은 것으로 나타났다. Sigma $0.1 \%$ 와 냉수 $0.1 \%$ 를 비교한 결과 회수율과 total IgY, sepecific IgY의 함량면에서는 Sigma $0.1 \%$ 가 더 좋은 것으로 나타났으나 경제적인 면을 고려할 때 냉수 가용성 카라기난을 사용 하는 것이 적절할 것으로 사료된다.

Hatta (1990)의 보고를 보면 다른 gum solution

Table 1. Comparison of IgY separation methods

\begin{tabular}{|c|c|c|c|}
\hline & Carrageenans & $\begin{array}{l}\text { Recovery rate } \\
(\%)\end{array}$ & $\begin{array}{l}\text { Amount of } \\
\text { recovery }(\mathrm{mL})^{*}\end{array}$ \\
\hline 1 & $\lambda$-carrageenan (Sigma C-3889) & 0.1 & 110 \\
\hline 2 & MSC \#10386 (hot water soluble) & 0.1 & 95 \\
\hline 3 & MSC \#10386 (hot water soluble) & 0.2 & 93 \\
\hline 4 & MSC \# 10387 (cold water soluble) & 0.1 & 105 \\
\hline 5 & MSC \#10387 (cold water soluble) & 0.2 & 110 \\
\hline 6 & $\begin{array}{l}\text { MSC \#10387 (cold water soluble) : } \\
\text { MSC \#10386 (hot water soluble) }=1: 1\end{array}$ & 0.1 & 80 \\
\hline 7 & $\begin{array}{l}\text { MSC \#10387 (cold water soluble) : } \\
\text { MSC \#10386 (hot water soluble) }=1: 1\end{array}$ & 0.2 & 104 \\
\hline
\end{tabular}

A) recovery of WSF separated using each carrageenan 
Fig. 5. Average of total $\lg Y$ content.
A : $\lambda$-carrageenan (Sigma C-3889) $0.1 \%$
B : hot water soluble $0.1 \%$
C : hot water soluble $0.2 \%$
D : cold water soluble $0.1 \%$
E : cold water soluble $0.2 \%$
F : hot water soluble + cold water soluble $0.1 \%$
$\mathrm{G}$ : hot water soluble + cold water soluble $0.2 \%$

Fig. 6. Average of specific IgY content.
A : $\lambda$-carrageenan (Sigma C-3889) $0.1 \%$
$\mathrm{B}$ : hot water soluble $0.1 \%$
C : hot water soluble $0.2 \%$
D : cold water soluble $0.1 \%$
E : cold water soluble $0.2 \%$
F : hot water soluble + cold water soluble $0.1 \%$
$\mathrm{G}$ : hot water soluble + cold water soluble $0.2 \%$

에 비해 $\lambda$-카라기난이 난황 단백질의 활성을 저해하지 않으면서 난황 지질을 선택적으로 제 거하였다. 한편 손 등(1998)의 연구를 보면 $\lambda$-카라기난의 방법의 경우 gammaYolk $^{\mathrm{TM}}$, EGGstract $^{\mathrm{TM}}$ 보다 $\operatorname{IgY}$ 의 회수율이 매우 높아 1 $\mathrm{g}$ 당 각각 $11.3,1.7,1.8 \mathrm{mg}$ 으로 나타났으며 분 리시간은 20 분, 1 시간이상, 35 분 가량씩 소요되 었다. 따라서 $\lambda$-카라기난이 경제성, 간편성, 효율성에서 우수하여 많은 양의 난황 항체를 생산할 때 유용한 것으로 나타났다.

이번 연구에서 다양한 종류의 카라기난 효율 을 비교한 결과 냉수가용성 카라기난이 수율도 높고 가격이 저렴하여 대량생산을 고려하였을 때 냉수 가용성 카라기난을 사용하는 것이 적 절할 것으로 사료된다.

\section{4. 항체의 $\mathrm{pH} \cdot$ 열 안정성 시험}

WSF을 $\mathrm{pH}$ 2에서 $\mathrm{pH}$ 10까지 변화시켜 total $\mathrm{IgY}$ 의 역가를 측정한 결과는 Fig. 7과 같다. $\mathrm{pH}$ 2에서 $\mathrm{pH}$ 4에서는 total $\mathrm{IgY}$ 함량이 급격히 감 소하여 $\mathrm{IgY}$ 가 강산에 불안정한 경향을 보이는 것으로 나타났으나, $\mathrm{pH} 5$ 에서 $\mathrm{pH} 10$ 까지는 매 우 안정된 상태를 유지하였다. 냉동 건조된 $\mathrm{IgY}$ 분말을 재용해시켜 제조한 $1 \%, 2 \% \operatorname{IgY}$ 용 액에서도 specific $\mathrm{IgY}$ 에서의 잔존의 경향이 WSF과 유사한 결과를 보여 주었다. $\mathrm{pH}$ 가 specific IgY에 미치는 영향은 Fig. 8에 나타내 었다. WSF 또는 냉동 건조된 $\operatorname{IgY}$ 분말을 용해 시켜 제조한 $1 \%, 2 \% \operatorname{IgY}$ 용액 모두 $\mathrm{pH} 2$ 와 $\mathrm{pH} 3$ 에서 specific $\mathrm{IgY}$ 잔존활성이 급격히 감소 하였으나 $\mathrm{pH}$ 4에서 $\mathrm{pH} 10$ 까지는 매우 안정적 인 것으로 나타났다.

Total $\mathrm{IgY}$ 활성이 높은 가장 $\mathrm{pH}$ 7과 비교하 였을 때 WSF와 냉동 건조된 $\operatorname{IgY}$ 분말을 용해 시켜 제조한 $1 \%$ 용액, 냉동 건조된 $\mathrm{IgY}$ 분말을 용해시켜 제조한 $2 \%$ 용액의 total $\operatorname{IgY}$ 함량은 각각 $35 \%, 65 \% 80 \%$ 로 나타났다. 이로서 $\mathrm{WSF}$ 은 $\mathrm{IgY}$ 분말로 제조된 용액보다 $\mathrm{pH}$ 의 영향을 더 많이 받는 것으로 나타났다. 
한편, specific $\mathrm{IgY}$ 의 활성은 total $\mathrm{IgY}$ 와는 달 리 $\mathrm{pH}$ 9에서 가장 높은 활성을 보여 주었는데 이는 $\operatorname{IgY}$ 구조 내에서 S. gallinarum에 대한 specificity를 주는 구조 부위가 알칼리에서 더 안정적인 것이 아닐까 추측되었다. $\mathrm{pH}$ 9와 비 교하여 $\mathrm{pH}$ 4에서 $\mathrm{WSF}$ 와 냉동 건조된 $\mathrm{IgY}$ 분 말을 용해시켜 제조한 $1 \%$ 용액, 냉동 건조된 $\operatorname{IgY}$ 분말을 용해시켜 제조한 $2 \%$ 용액의 specific IgY 함량은 각각 $79 \%, 67 \%, 42 \%$ 로 나 타났다.

한편 손 등(1998)의 연구를 보면 항-Streptococcus mutans 특이 $\mathrm{IgY}$ 잔존활성이 $\mathrm{pH}$ 9에서 급격히 감소하였으나 $\mathrm{pH}$ 4에서 $\mathrm{pH}$ 8까지는 매 우 안정적인 것으로 나타났는데 이로서 항- $S$. gallinarum specific $\mathrm{IgY}$ 잔존 활성이 항-S. mutans specific IgY보다 좀 더 안정적인 것으로 나타났다.

위를 종합하여 가공처리 시의 여러 가지 상 황을 고려하였을 때, 지금까지의 결과를 토대 로 $\mathrm{pH} 4$ 미만의 강산에 의한 가공 공정은 $\mathrm{IgY}$ 가공법으로 적절치 않는 것으로 사료되었다. 그러나 대부분의 가공 조건이 $\mathrm{pH} 4$ 이상에서 이루어지므로 $\operatorname{IgY}$ 를 이용한 제품의 생산 시에 는 일반적인 가공 조건에서는 $\operatorname{IgY}$ 의 활성이 잘 유지 될 수 있는 것으로 나타나 $\mathrm{IgY}$ 활용의 범 용성이 입증되었으며 대부분의 가공 조건에서 도 잘 견딜 수 있는 것으로 사료되었다.

$\mathrm{IgY}$ 의 열에 의한 안정성은 가열하지 않은 $\mathrm{IgY}$ 의 활성을 100 으로 기준하여 조사하였다. $\mathrm{WSF}$ 와 냉동 건조된 $\mathrm{IgY}$ 분말을 용해시켜 제조 한 $1 \%$ 용액, 냉동 건조된 $\operatorname{IgY}$ 분말을 용해시켜 제조한 $2 \%$ 용액을 열처리 한 후에 잔존 활성 을 나타난 결과, 처리 온도와 시간이 증가할수 록 $\mathrm{WSF}$, 냉동 건조된 $\mathrm{IgY}$ 분말을 용해시켜 제 조한 $1 \%$ 용액, 냉동 건조된 $\mathrm{IgY}$ 분말을 용해시 켜 제조한 $2 \%$ 용액 모두 total IgY 잔존 함량은 서서히 감소하는 경향을 나타내었다. 특히 80
${ }^{\circ} \mathrm{C} 5$ 분 가열 처리한 경우에는 WSF 과 냉동 건 조된 $\mathrm{IgY}$ 분말을 용해시켜 제조한 $1 \%$ 용액, 냉 동 건조된 $\mathrm{IgY}$ 분말을 용해시켜 제조한 $2 \%$ 용 액이 각각 $3.95 \%, 0.85 \%, 0.47 \%$ 로 total $\operatorname{IgY}$ 잔 존 함량 크게 감소하였다.

Fig. 7. Total $\mathrm{Ig} \mathrm{Y}$ stability by various $\mathrm{pH}$.

Fig. 8. Specific IgY stability by various $\mathrm{pH}$.

그러나 $70^{\circ} \mathrm{C} 5$ 분 가열에서는 WSF와 냉동 건 조된 $\mathrm{IgY}$ 분말을 용해시켜 제조한 $1 \%$ 용액, 냉 동 건조된 $\mathrm{IgY}$ 분말을 용해시켜 제조한 $2 \%$ 용 액은 각각 $62 \%, 58 \% 62 \%$ 로 나타나 $\mathrm{IgY}$ 용액 의 가공 처리 시 낮은 온도의 살균과정 등에서 잘 견딜 수 있는 것으로 사료된다. 한편 $70^{\circ} \mathrm{C}$ 10 분 가열에서는 WSF과 냉동 건조된 $\mathrm{IgY}$ 분말 을 용해시켜 제조한 $1 \%$ 용액, 냉동 건조된 $\mathrm{IgY}$ 분말을 용해시켜 제조한 $2 \%$ 용액의 $\mathrm{IgY}$ 의 잔 
Fig. 9. Total $\lg Y$ stability by various temperature.

손 등(1998)의 연구를 보면 항-Streptococcus mutans 특이 $\operatorname{IgY}$ 의 $\mathrm{pH}$ 잔존활성이 $70^{\circ} \mathrm{C} 5$ 분에 서 급격히 감소하였으나 $\mathrm{pH}$ 4에서 $\mathrm{pH}$ 8까지는 매우 안정적인 것으로 나타나는 것으로 보아 항-Salmonella gallinarum 특이 $\mathrm{IgY}$ 의 $\mathrm{pH}$ 잔존 활성이 좀더 안정적인 것으로 나타났다.

\section{5. 전체 lgY중에서 항-Salmonella gallinarum 특이항체의 함량분석 방법}

난황중의 $\mathrm{IgY}$ 중에서 S. gallinarum에 specific 한 $\mathrm{IgY}$ 의 함량을 조사하기 위하여 WSF를 여러 농도의 S. gallinarum와 반응시켜 면역복합체를 형성시킨 후 원심분리로 이를 제거하고 상징액 중에 잔존하는 단백질의 양을 $280 \mathrm{~nm}$ 에서 측 정하여 Fig. 11 같은 결과를 얻었다. 여기에서 상대적인 항원의 농도가 0.6 일 때 상징액의 흡 광도는 거의 바닥값을 나타내어 S. gallinarum 에 대한 특이항체는 거의 제거되었음을 알 수 있다. 따라서 방법에 명시한 식에 의하여 수용 성 단백질 중 S. gallinarum 특이항체의 비율을 구하면 $23 \%$ 이다. 즉 계란 total $\mathrm{IgY}$ 함량 중

Fig. 10. Specific IgY stability by various temperature.

존 함량은 각각 $45 \%, 45 \%, 39 \%$ 로 활성이 감소 하는 것으로 나타났다. 마찬가지로 specific $\mathrm{IgY}$ 의 역가는 온도가 증가할수록 서서히 감소하는 경향을 나타내었으며, 냉동 건조된 $\mathrm{IgY}$ 분말을 용해시켜 제조한 $1 \%$ 용액의 역가 비율의 감소 가 $\mathrm{WSF}$ 에 비해 다소 높았다. $80^{\circ} \mathrm{C}$ 에서는 total $\mathrm{IgY}$ 의 경우와 마찬가지로 specific $\mathrm{IgY}$ 의 역가 가 거의 나타나지 않았다(Fig. 9, Fig. 10). 한편
Fig. 11. Quantitative immunoprecipitation of specific IgY and Salmonella gallinarum. The results were shown as the absorbance of the supernatants after removal of the immune complexes. 
Specific $\operatorname{IgY}=\frac{\mathrm{A}_{280} \text { of blank }-\min \mathrm{A}_{280}}{\mathrm{~A}_{280} \text { of blank }} \times 100 \%$

$23 \%$ 가 S. gallinarum 특이항체임을 알 수 있다. 난황 항체의 분리 효율은 난황으로부터 항충치 항체의 분리 및 그 특성(손 등, 1998)에서 난황 항체중에 함유된 Streptococcus mutans의 특이 항체의 비율은 $61 \%$ 으로 나왔지만 본 실험의 경우 S. gallinarum 특이항체는 이 보다는 다소 낮다는 것을 알 수 있었다.

\section{IV. 요 약}

가금티푸스 유발균인 Salmonella gallinarum 대항하는 항체의 함량이 높은 계란을 생산하기 위해 면역처리 후 산란계의 난황에서 항체를 분리하여 총 $\operatorname{IgY}$ 와 특수 $\mathrm{IgY}$ 의 함량의 변화와 그 특성을 조사하였다. 먼저 난황으로부터 항 체의 수율과 경제적인 측면을 비교하기 위하여 난황 분리된 난황 $25 \mathrm{~g}$ 을 $\lambda$-카라기난(Sigma C-3889) $0.1 \%$, 냉수 가용성(MSC \# 10387) $1 \%$, $2 \%, 90{ }^{\circ} \mathrm{C}$ 가용성 (MSC \#10386) $1 \%, 2 \%$ 및 냉수 가용성 $(0.1 \%): 90^{\circ} \mathrm{C}$ 가용성 $(0.1 \%)=1: 1$ $1 \%, 2 \%$ 로 사용하여 분리하는 하였을 때 $\lambda-$ 카 라기난 $0.1 \%$, 냉수 가용성 $1 \%$ 비교적 높은 회 수율과 total $\operatorname{IgY}$, specific $\operatorname{IgY}$ 함량을 나타내었 지만 $\lambda$-카라기난 $0.1 \%$ 가 더 나은 것으로 나 타났다. Specific $\operatorname{IgY}$ 는 마지막 백신 접종 후 44 주간까지 꾸준히 검출되고 있는 것으로 나타났 다. 산도 변화에 의한 total $\mathrm{IgY}$ 의 잔존 함량을 보면 $\mathrm{pH} \quad 5^{\sim 9}$ 범위에서 $70 \%$ 이상 잔존하며, specific $\operatorname{IgY}$ 도 $\mathrm{pH} 4{ }^{\sim}$ 에서 $74 \%$ 이상 존재하 여 산에 대하여 대체로 안정적임을 알 수 있었 다. 열처리 후 조항체 용액을 total $\mathrm{IgY}$, specific $\operatorname{IgY}$ 역가 높게 유지되는 것을 관찰 할 수 있었 다. 이로써 난황으로부터의 면역 항체 생산의 가능성이 확인되었고 이러한 $\mathrm{IgY}$ 는 추출과 가 공처리 등에 의해 비교적 안정적인 것으로 나
타나 $\operatorname{IgY}$ 를 이용한 가금티푸스의 예방 또는 치 료용의 대량 생산 가능성이 높은 것으로 사료 되었다.

\section{$\mathrm{V}$. 인 용 문 헌}

1. Hatta, H., Sim, J. S. and Nakai, S. 1988. Separation of phospholipids from egg yolk and recovery of water soluble proteins. J. Food Sci. 53(2):425-431.

2. Lee, K., Ametani, A., Shimizu, M., Hatta, H., Yamamoto, T. and Kimnogawa, S. 1991. Production and characterization of anti-human insulin antibodies in the hen's egg. Agric Biol. Chem., 55(8):2141-2143.

3. Larsson, A., Balow, R. M., Linda, T. L. and Forsberg, P. O. 1995. Chicken antibodies ; Taking advantage of evolution - A review. Poultry Sci. 72(9):1807-1812.

4. Bade, H. and Stegemann, H. 1984. Rapid method of extraction antibodies from hen egg yolk. J. Immunol. Methods. 72:421-426.

5. Hatta, H., Kim, M. and Yamamoto, T. 1990. A novel isolation method for hen egg yolk antibody "IgY". Agric. Biol. Chem. 54(10):231-2535.

6. Polson, A. and Von Wechmar, M. B. 1980. Insolation of viral $\mathrm{IgY}$ antibodies from yolks of immunized hens. Immunol. Commun. 9(4):475.

7. 한찬규, 이복희, 윤칠석, 성기승, 이남형. 2000. 몇 가지 사료 첨가제가 계란의 특성성분에 미치 는 영향. 한국동물자원과학회지. 42(1):73-85.

8. 모인필. 1995. 중추 구입 후 가금티프스 발생으 로 폐사 다발. 양계연구. 12:52-53.

9. 나만체. 1999. 국내 산란계에서 다발하는 주요 질병 및 대책. 월간양계. 2: 85-89.

10. 박경윤. 1995. 양계장의 살모넬라 감염실태와 대 책. 양계연구. 6:54-58.

11. 김영붕, 노정해, 손동화, 김희주, 성기승, 이남형. 2000. Streptococcus mutans에 specific IgY의 항균 력. 한국식품과학회지. 32(6):1319-1325.

12. 손동화, 노정해, 김영붕, 한찬규, 성기승, 이남형. 1998. 난황으로부터 항충치 항체의 분리 및 그 특성. 한국식품과학회지. 30(5):1029-1034. 
Rho et al. ; Effect of Specific IgY from Yolk

13. 노정해, 김영붕, 한찬규, 성기승, 이남형, 손동화. 1999. 산란계의 연령과 면역주기에 따른 난황 중 의 Streptococcus mutans 특이 항체 함량. 한국동 물자원과학회지. 41(5):563-574.

14. 이남형, 노정해, 한찬규, 성기승. 1999. 여러 가지 산란계 사료 첨가제가 계란의 $\mathrm{IgY}$ 수준과 산란 율에 미치는 영향. 한국동물자원과학회지. 41(2): 155-156.
15. 오경록. 1999. 가금용 살모넬라균 백신의 장단점. 월간양계. 1:52-53.

16. 유종철. 1999. 전체 가금 질병의 101 가지 종류와 국내 필드 대처 상황. 현대양계. 1:54-59.

17. 오경록. 1995. 살모넬라균의 종합적 방역 프로그 램. 양계연구. 6:41-46.

(접수일자 : 2005. 2. 1./ 채택일자 : 2005. 7. 12.) 